\title{
Soil moisture remote-sensing applications for identification of flood- prone areas along transport infrastructure
}

\author{
Anna-Klara AhImer ${ }^{1}\left[\right.$ $\cdot$ Marco Cavalli $^{2} \cdot$ Klas Hansson $^{3} \cdot$ Alexander J. Koutsouris $^{4} \cdot$ Stefano $_{\text {Crema }}{ }^{2} \cdot$ Zahra Kalantari $^{5}$
}

Received: 26 November 2017 / Accepted: 26 May 2018 / Published online: 12 July 2018

(c) The Author(s) 2018

\begin{abstract}
The expected increase in precipitation and temperature in Scandinavia, and especially short-time heavy precipitation, will increase the frequency of flooding. Urban areas are the most vulnerable, and specifically, the road infrastructure. The accumulation of large volumes of water and sediments on road-stream intersections gets severe consequences for the road drainage structures. This study integrates the spatial and temporal soil moisture properties into the research about flood prediction methods by a case study of two areas in Sweden, Västra Götaland and Värmland, which was affected by severe flooding in August 2014. Soil moisture data are derived from remote-sensing techniques, with a focus on the soil moisture-specific satellites ASCAT and SMOS. Furthermore, several physical catchments descriptors (PCDs) are analyzed and the result shows that larger slopes and drainage density, in general, mean a higher risk of flooding. The precipitation is the same; however, it can be concluded that more precipitation in most cases gives higher soil moisture values. The lack, or the dimensioning, of road drainage structures seems to have a large impact on the flood risk as more sediment and water can be accumulated at the road-stream intersection. The results show that the method implementing soil moisture satellite data is promising for improving the reliability of flooding.
\end{abstract}

Keywords Flooding $\cdot$ Road infrastructure $\cdot$ Soil moisture $\cdot$ Remote sensing $\cdot$ Precipitation

This article is part of a Topical Collection in Environmental Earth Sciences on "Learning from spatial data: unveiling the geo-environment through quantitative approaches", guest edited by Sebastiano Trevisani, Marco Cavalli, Jean Golay, and Paulo Pereira.

Electronic supplementary material The online version of this article (https://doi.org/10.1007/s12665-018-7704-z) contains supplementary material, which is available to authorized users.

Zahra Kalantari

zahra.kalantari@natgeo.su.se

Anna-Klara Ahlmer

a.ahlmer@hotmail.com

1 Trivector Traffic, Stockholm, Sweden and KTH, Stockholm, Sweden

2 Research Institute for Geo-Hydrological Protection, National Research Council, Padua, Italy

3 Swedish Transport Administration (Trafikverket), 17290 Stockholm, Sweden

4 Department of Physical Geography, Stockholm University, 10691 Stockholm, Sweden

5 Department of Physical Geography and Bolin Centre for Climate Research, Stockholm University, 10691 Stockholm, Sweden

\section{Introduction}

Global warming is now proceeding faster than ever before, most likely as a result of increased pressure from human activities. The EU Green Paper report (European Commission 2007) identified Scandinavia as one of the most vulnerable areas to climate change associated with global warming, due to the large increases in precipitation which are to be expected. Precipitation patterns in Sweden are predicted to change during winter, spring, and autumn (Holgersson et al. 2007). Climate change will most likely increase the frequency of intense short-term precipitation events, which would have consequences for runoff in urban areas considering the large areas of impervious surfaces which they contain, which limits infiltration capacity (Bates et al. 2008; Lenderink and van Meijgaard 2008; Olsson and Foster 2013). The increase in runoff for Scandinavia and Sweden is projected to be around $20 \%$ more by 2090 compared with 1980-1999 (Bates et al. 2008).

The development of floods depends on several factors, including precipitation patterns (intensity, volume, and timing), drainage basin conditions (morphometry and soil 
characteristics), wetness, urbanization, and the presence of embankments, reservoirs, and dams. A lack of response areas and human activities on floodplains further enhances the risk of flood damage. Flooding risk is also dependent on the degree of saturation. Changes in precipitation and evapotranspiration rates modify the soil moisture content, which in turn changes the infiltration, groundwater recharge, and runoff ratios (Nigel et al. 2001). Several studies have concluded that the initial soil moisture conditions can explain the difference between minor and major flooding effects (Berthet et al. 2009; Brocca et al. 2008; Crow et al. 2005). Accurate and timely data on soil moisture content are thus essential for enhanced flood prediction (Kerr et al. 2010).

Studies show that climate change has, most likely already, had an impact on the intensity and frequency of floods (Bates et al. 2008). Twice as many flood events per decade occurred between 1996 and 2005 compared with 1950-1980, with an associated fivefold increase in economic losses (Kron and Berz 2007). This is mainly due to population increase, economic growth, changes in land use, and development in vulnerable areas (Kron and Berz 2007).

Some studies have concluded that climate change will have significant impacts on the road infrastructure in Scandinavia and also in other countries (Bates et al. 2008; Holgersson et al. 2007; Kalantari and Folkesson 2013). Road infrastructure is affected by high stream flows, precipitation, temperature, sea-level rise, wind, and ice coating. Furthermore, prolonged precipitation can raise the groundwater level, increase the pore pressure in the soil, and hence affect slope stability. The impacts on low-lying roads, underpasses, and culverts become more problematic (Nordlander et al. 2007) with an increased risk of erosion and high flows. This is particularly problematic considering that current Swedish infrastructure is not designed to accommodate predicted future changes in the climate (Kalantari et al. 2014; European Commission 2007). While some drainage facilities (e.g., bridges and culverts) in Sweden have been dimensioned for 50-year flows (Vägverket 2002, 2008), most of the existing roads was constructed before the need of climate change adaptation in the transport sector was realized. When potential changes in climate (Vägverket 2008) have been taken into consideration, the adjusted dimensioning has rather been using simple static correction factors and lacks predictive capabilities representable for land-use changes and climate change conditions (Kalantari et al. 2015). In addition to climate change, the growth in population and economic wealth place further demands on the urban landscape, since it often requires infrastructures to expand in risk prone areas (Suarez et al. 2005).

There is an additional cause for concern due to the adverse effects of environmental changes to urban areas and urban infrastructure because of their associated long lifetimes and high investment costs (European Commission
2007; Kalantari and Folkesson 2013). Urban expansion close to coastal areas and watercourses further increases the risk of flooding (Holgersson et al. 2007). Moreover, road infrastructure also has an impact on the hydrological response, with consequences for drainage patterns and the natural landscape (Tague and Band 2001; Wemple et al. 2001). Consideration of urban areas in flood prediction research is, therefore, paramount, especially considering a projected increase of urban areas and their associated impermeable surface (Kalantari et al. 2017; Brimicombe 2009; Olsson and Foster 2013; Vägverket 2008; Karlsson et al. 2017).

Mass movement of water and sediment can also cause damage to drainage structures. Problems occur when roads cross a catchment and the upstream watercourses are concentrated in a single drainage facility (e.g., a culvert or pipe) to pass under the road. This concentration of runoff modifies the normal flow and leads to increased erosion over a large distance if the stream bed is not adapted to these altered hydraulic conditions. If the runoff exceeds the capacity of the drainage facility, the road will act as a dam and induce flooding (Brencic et al. 2009). Therefore, it is essential to identify road-stream intersections that are at risk of future flooding. Only a few studies so far have focused on assessing road flood risks over large scales using Geographic Information System (GIS) mapping and integration of key landscape characteristics such as topography, land use and soil data, road characteristics, and landscape morphology (Kalantari et al. 2014, 2017; Michielsen et al. 2016).

In this study, we investigate the potential to use spatial and temporal soil moisture distribution and other key landscape characteristics as defined by Michielsen et al. (2016) and Kalantari et al. (2014) to develop a method for the identification of flood-prone areas. As a proof-of-concept, the data-driven method developed was applied to the identification of critical road-stream intersection sites within two case studies located in south-west Sweden. Development of such a method can be helpful for optimal flood management, since it helps to increase awareness among decision makers [e.g., Swedish Transport Administration (STA)] when planning maintenance and promoting solutions for preventing the risk of flooding. The primary area of application of the presented method would be for identifying the most critical points along roads that have a high risk of flooding. Once the location of these critical points is known, protection and monitoring actions can be established.

\section{Soil moisture and remote sensing}

The soil moisture content differs vertically and horizontally and, therefore, varies with soil volume. This is highly relevant for the choice of the measurement method, as some approaches might only provide estimates of the top few centimeters, as is the case with remote-sensing technology 
(Seneviratne et al. 2010). Thus, near-surface soil moisture and volumetric soil moisture content, i.e., the ratio between the volume of water and volume of soil (unit $\mathrm{m}^{3} / \mathrm{m}^{3}$ ), is most commonly used in remote sensing (Kerr et al. 2010).

Soil type, landscape characteristics, and atmospheric variables are the main controls of the spatial and temporal variability of soil moisture (Barrett and Petropoulos 2012; SMAP 2017). Parameters that affect soil moisture change in response to precipitation input are, for example, soil texture (especially particle size), which determine the water-holding capacity of the soil. Other landscape characteristics that affect the response are soil depth, underlying bedrock, slope, and altitude relative to the surrounding landscape (Kalantari et al. 2014; Petropoulos et al. 2013).

Passive and active microwave sensors have been identified as the most consistent providers of temporal and spatial retrieval of soil moisture data (Barrett and Petropoulos 2012), although certain limitations occur. Passive sensors are affected by cloud cover, which is a frequently occurring situation during flood events. Cloud removal methods must thus be applied to obtain any useful data. However, passive sensors have been used in several flood studies, due to other advantages like abundant spectral features of multi-spectral imagery with long temporal availability, which is suitable for evaluating long-term effects of flooding (Zhang et al. 2014). Active sensors have the ability to penetrate clouds and thus derive information during precipitation events, but the long revisit time restricts the use of rapid responses. However, several active sensors with higher temporal and spatial resolution have been launched (e.g., COSMO-SkyMed, TerraSAR-X, and Envisat ASAR), thus enhancing the conditions for effective flood monitoring (Pierdicca et al. 2013; Pulvirenti et al. 2011; Zhang et al. 2014). The retrieval of soil moisture data depends on large differences between the dielectric constant of water and dry soil, as the soil moisture content influences the soil electrical permittivity (Pierdicca et al. 2013).

The spatial and temporal heterogeneity in soil moisture content limits the ability to measure soil moisture accurately over large areas. During recent decades, several approaches using satellite-based remote sensing to estimate soil moisture content have been developed in an attempt to overcome this issue. Typically, remotely sensed soil moisture estimates are based on measurements using the microwave, SAR, optical, or thermal infrared (TIR) sensors (Barrett and Petropoulos 2012; Kerr et al. 2010). Moran et al. (2004) evaluated the spectral measurements for surface soil moisture and compared optical, microwave, and synthetic aperture radar (SAR) approaches. Optical sensors and thermal imaging radar (TIR) have fine spatial resolution and cover large areas, and there are several satellite sensors available. However, the penetration of the surface is minimal $(\sim 1 \mathrm{~mm})$, and cloud cover and vegetation block the measurements, making the relation to soil moisture weak. Microwave sensors show a strong relationship to soil moisture data retrieval, penetrate the surface down to $5 \mathrm{~cm}$, have broad coverage, and are not affected by cloud cover. However, the coarse spatial resolution is a disadvantage, together with disturbances primarily from vegetation and surface roughness. Synthetic aperture radar (SAR) was until recently limited by a coarse revisit time, but, with the development of different sensors, high temporal frequencies are now possible, together with fine spatial resolution. SAR has a suitable penetration depth of $5 \mathrm{~cm}$, is not affected by clouds, and shows a strong relation to soil moisture. As with microwave sensors, the disturbances are from surface roughness and, to some extent, vegetation (Moran et al. 2004).

Commonly, sensors capturing the C-band (4-8 GHz) and the L-band (1-2 GHz) are used for soil moisture estimations. While both have been successfully implemented (e.g., Pierdicca et al. 2013; Gruber et al. 2013; Albergel et al. 2012; Entekhabi et al. 2010), the previous studies have shown that the L-band is more suitable due to its low sensitivity to vegetation and greater penetration into the soil (Kerr 2007). SAR, on the other hand, have an equal capacity as microwave sensors for soil penetration $(5 \mathrm{~cm})$ and has the ability to penetrate clouds. Moran et al. (2004) thus concluded that soil moisture products based on SAR often is preferred over those based on the microwave.

Hydrological applications require good temporal resolution, as the revisit time limits the ability to use soil moisture data in operational flood forecasting models if the data are not available when needed. Many of the current sensors allow retrieval of data over around 10-35 days, which might not be adequate for applications in hydrology (Table 1) (Kornelsen and Coulibaly 2013; Moran et al. 2004).

The major advantage of SAR sensors when working with soil moisture is the fine spatial resolution, which should be set in relation to the low temporal and radiometric resolution. This has resulted in the development of platforms like SMOS, SMAP, ASCAT, and AMSR-E as a complement with lower retrieval error, near real-time capabilities, and 1-3 days temporal resolution, but coarse spatial resolution (Table 2). The coarse spatial resolution is a disadvantage when applying the method in local areas, but this can be outweighed by the temporal resolution of a few days and the opportunities for near real-time applications. The ASCAT sensor was the first with near real-time capabilities and data can be provided $130 \mathrm{~min}$ after retrieval, which enhances the ability to monitor flooding as it occurs (Albergel et al. 2012; Brocca et al. 2017). The need for finer spatial resolution has prompted work to disaggregate large-scale products to enable usage in small-scale catchments, where the disaggregation of the ASCAT $25-\mathrm{km}$ resolution product to a $1-\mathrm{km}$ product is one option (Wagner et al. 2013). The satellites identified 
Table 1 Summary of several sensors, their characteristics, and previous studies

\begin{tabular}{|c|c|c|c|c|c|c|}
\hline Sensor & Start date & Band & Type & Spatial resolution & Temporal resolution & Previous studies \\
\hline Sentinel 1 (SAR) & 2014 & C-band & SAR & $5-20 \mathrm{~m}$ & $\begin{array}{l}6 \text { days ( } 3 \text { days } \\
\text { for Europe and } \\
\text { Canada) }\end{array}$ & $\begin{array}{l}\text { Gruber et al. (2013), } \\
\text { Hornacek et al. (2012), } \\
\text { Petropoulos, Ireland, and } \\
\text { Barrett (2015) and Wagner } \\
\text { et al. (2009) }\end{array}$ \\
\hline TerraSAR-X (SAR) & 2007 & $\mathrm{X}$ - or C-band & SAR & $0.5-18 \mathrm{~m}$ & 11 days & Baghdadi et al. (2012) \\
\hline Cosmo-SkyMed (SAR) & 2008 & X-band & SAR & $1-100 \mathrm{~m}$ & $12 \mathrm{~h}$ & $\begin{array}{l}\text { Pulvirenti et al. (2011) and } \\
\text { Refice et al. (2014) }\end{array}$ \\
\hline Radarsat (SAR) & 1995 and 2007 & C-band & SAR & $3-100 \mathrm{~m}$ & 24 days & $\begin{array}{l}\text { Bonn and Dixon (2005) and } \\
\text { Hassaballa et al. (2014) }\end{array}$ \\
\hline Envisat ASAR & 2002 and 2012 & C-band & SAR & $30 \mathrm{~m}$ & 3 days & Saran et al. (2014) \\
\hline Landsat $7 / 8$ & $1999 / 2013$ & X-band & Passive sensor & $30 \mathrm{~m}$ & 16 days & $\begin{array}{l}\text { Wang et al. (2002) and Zhang } \\
\text { et al. (2014) }\end{array}$ \\
\hline
\end{tabular}

Table 2 Main characteristics of sensors with a better temporal resolution

\begin{tabular}{|c|c|c|c|c|c|c|}
\hline Sensor & Start date & Band & Type & Spatial resolution & Temporal resolution & Previous studies \\
\hline ASCAT & 2007 & C-band & Active radar scatterometer & $25 \mathrm{~km}$ & 1,5 days & $\begin{array}{l}\text { Albergel et al. (2012), Barrett and } \\
\text { Petropoulos (2012), Bartalis } \\
\text { et al. (2007), Brocca et al. } \\
\text { (2017), Brocca et al. (2011), } \\
\text { Gruber et al. (2013) and Lacava } \\
\text { et al. (2012) }\end{array}$ \\
\hline SMOS & 2009 & L-band & $\begin{array}{l}\text { Passive interferometric radiom- } \\
\text { eter }\end{array}$ & $50 \mathrm{~km}$ & $2-3$ days & $\begin{array}{l}\text { Albergel et al. (2012), Kerr et al. } \\
\text { (2010), Lacava et al. (2012), } \\
\text { Parrens et al. (2012) and Piles } \\
\text { et al. (2014) }\end{array}$ \\
\hline AMSR-E & 2012 & C-band & Passive microwave radiometer & $25 \mathrm{~km}$ & 1 day & $\begin{array}{l}\text { Brocca et al. (2011), Lacava et al. } \\
\text { (2012) and Njoku et al. (2003) }\end{array}$ \\
\hline SMAP & 2015 & L-band & Radiometer & $36 \mathrm{~km}$ & $2-3$ days & $\begin{array}{l}\text { Entekhabi et al. (2010) and Lak- } \\
\text { shmi (2013) }\end{array}$ \\
\hline
\end{tabular}

as most suitable for the aim of the study were the ASCAT sensor, for which both the $25 \mathrm{~km}$ spatial resolution product and the 1-km product were assessed, and the SMOS satellite.

Remote-sensing methods have the advantage that it can provide soil moisture estimates over large areas at a global scale. Coarse spatial and temporal resolution, along with limited depth signal penetration (i.e., the thickness of measured soil), might, however, be obstacles in hydrological applications. Another issue of some sensors used for remote sensing of soil moisture is that the signal may be blocked by cloud cover. This is a clear limitation in applications related to flood events and their associated precipitation. Even so, satellite-based estimates may still provide important information in regions where adequate monitoring of hydrological parameters is lacking (Gruber et al. 2013).

\section{Data and methodology}

In the following, we provide a step-by-step description of the method applied for the identification of flood-prone areas along transport infrastructure. The study areas were selected identifying flooded and non-flooded points. The method comprises four steps for each point and its corresponding catchment: (1) data collection of physical catchment descriptors (PCDs) representing land use, soil type, topography, and road characteristic from the previous studies done by Kalantari et al. $(2014,2017)$ and Michielsen et al. (2016); (2) data collection and calculation of precipitation data; (3) calculation of soil moisture from specific satellites ASCAT and SMOS; (4) analysis of PCDs, precipitation, and soil moisture patterns and their relation to flooded and non-flooded points along transport infrastructure. 


\section{Case studies}

The western parts of Sweden have been identified as being especially prone to increased runoff (Holgersson et al. 2007), and in 2014 , this region was affected by severe flooding, with major consequences for Västra Götaland and Värmland (Kalantari et al. 2017; Michielsen et al. 2016). Given the availability of data and information on this event, the areas of Västra Götaland and Värmland were chosen as case studies for this work (Fig. 1).

Västra Götaland has been identified as prone to flooding due to a future increase in precipitation and its history of intense short-term precipitation events (Holgersson et al. 2007). An example of such an event was when a heavy rainfall hit the area on the 19-20 August 2014 and caused multiple floodings. These floodings had severe consequences on roads, railways, buildings, and local people, owing to traffic delays, pressure on other modes of transportation, and electricity problems (Bohusläningen 2014-08-21; SVT 2014a, b).

Värmland was affected by severe flooding a few days later from the 21-25 August 2014, which mainly had consequences on the road infrastructures. The E18 highway close to Kristinehamn was closed as nearly $100 \mathrm{~mm}$ of precipitation fell in a short time during the night between 20 and 21 August (Sveriges Radio 2014). Several other areas around Kristinehamn, Karlstad, and Ölme were also affected by large amounts of water that damaged the road structure, drainage facilities, and drinking water reserves. Roads collapsed and all road and train traffic was interrupted, including both local and long distance trains (Nya Kristinehamnsposten 2014).

\section{Data inventory}

The soil type in Västra Götaland is characterized as rock (35\%) and clay (33\%), and forest is the main land use in the area, followed by agriculture (Fig. 2). In urban areas, the soil type is mainly clay or glacial till, and there are also large amounts of clay soils alongside roads. Impervious surfaces together with clay result in more runoff compared to the runoff in forest areas which has a larger capacity to restrain water. Several of the flooding-prone areas are also located close to agriculture, which might alter the flow path of the water. The soil type in Värmland is mainly till (21\%), clay $(14 \%)$, and rock (15\%). The land use is mainly characterized by forest and agricultural areas, with urban areas represented by the larger cities of Karlstad and Kristinehamn (Fig. 3). The glacial till or sandy soils dominate in urban areas, which, to some extent, allow better drainage of water than clay. However, large amounts of impervious surfaces increase the surface runoff.
The precipitation data in the case study areas were collected from two different sources: the ground station measurements of two stations in each area (SMHI 2017a) and radar measurements from the NORDRAD project (Berg et al. 2016). The radar data have a spatial resolution $2 \times 2 \mathrm{~km}$ and temporal resolution of $15 \mathrm{~min}$ at ten different tilt angles.

The present analysis is based on the previous research in the field by Kalantari et al. $(2014,2017)$ and Michielsen et al. (2016), and the same case study areas were used. In addition to the soil moisture and precipitation values, a number of characteristics of the catchment area (land use, soil type, and topography) and of roads called physical catchment descriptors (PCDs) were used. In total, 17 PCDs were considered (see Table A and B in the supplementary material) following from Kalantari et al. $(2014,2017)$ and Michielsen et al. (2016). All calculations and maps were made in Matlab and ArcMap 10.4.

An inventory of road drainage structures in flooded parts of the case study areas was made using the STA database BaTMan. This database manages, monitors, and provides information about bridges, tunnels, and other road-related constructions, although constructions with less than 2-m span width are not included in BaTMan (Trafikverket 2015). Google Maps (CNES, Airbus kartdata 2017) (accessed 2017-05-02) was used to complement with drainage structures at locations where no culverts or bridges are registered in BaTMan (see Fig. 1 or supplementary material $\mathrm{C}$ for all results).

\section{Satellite data}

Several satellites have the ability to provide soil moisture values. However, hydrological applications, especially soil moisture extraction, require a temporal resolution of a few days, which limits the number of suitable satellites. The requirement for soil moisture observations is a soil moisture accuracy of $0.04 \mathrm{~m}^{3} / \mathrm{m}^{3}$ or, better, a spatial resolution of less than $50 \mathrm{~km}$ (preferably lower). A revisit time of 1-2 days is optimal to determine soil moisture properties and a reasonable time acquisition is required (Kerr et al. 2010). All satellite data tested here are listed in Tables 1 and 2. The satellites identified as most suitable for the aim of the study were the ASCAT sensor, for which both the $25 \mathrm{~km}$ spatial resolution product and the $1-\mathrm{km}$ product were assessed, and the SMOS satellite.

\section{ASCAT}

The ASCAT satellite is an active microwave sensor and measures in C-band. The high temporal resolution of approximately 1.5 day, the multi-angle capability, the continuous measurements, and the near real-time capabilities (130 min after retrieval) of the ASCAT sensor make it the 

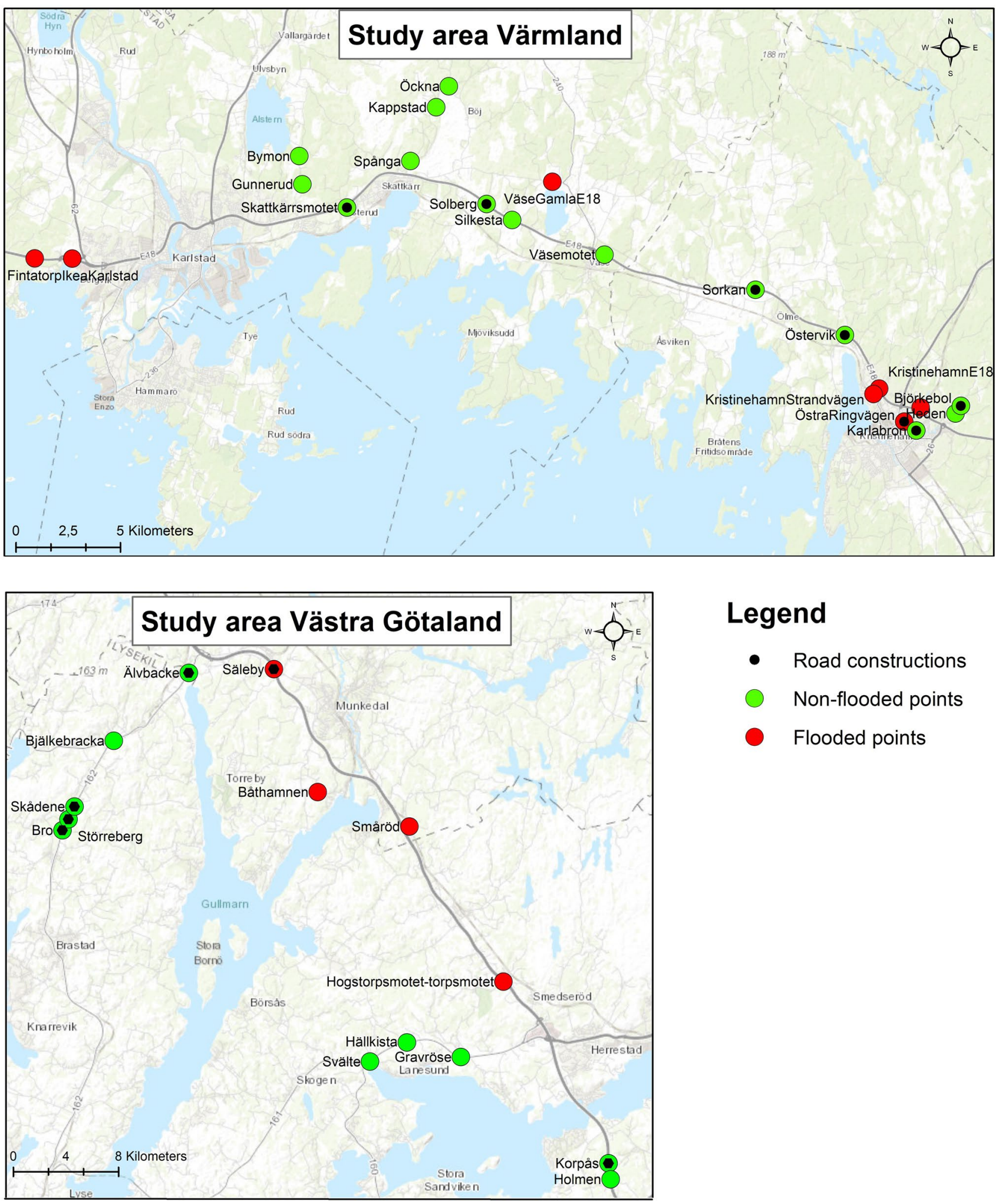

\section{Legend}

- Road constructions

Non-flooded points

- Flooded points

Fig. 1 Study area of Värmland and Västra Götaland with flooded and non-flooded points, and road drainage constructions

most suitable satellite for monitoring soil moisture changes (Brocca et al. 2017). The two swathes of the satellite result in a daily global coverage of approximately $82 \%$. An estimation of the water saturation of the topsoil layer is presented 


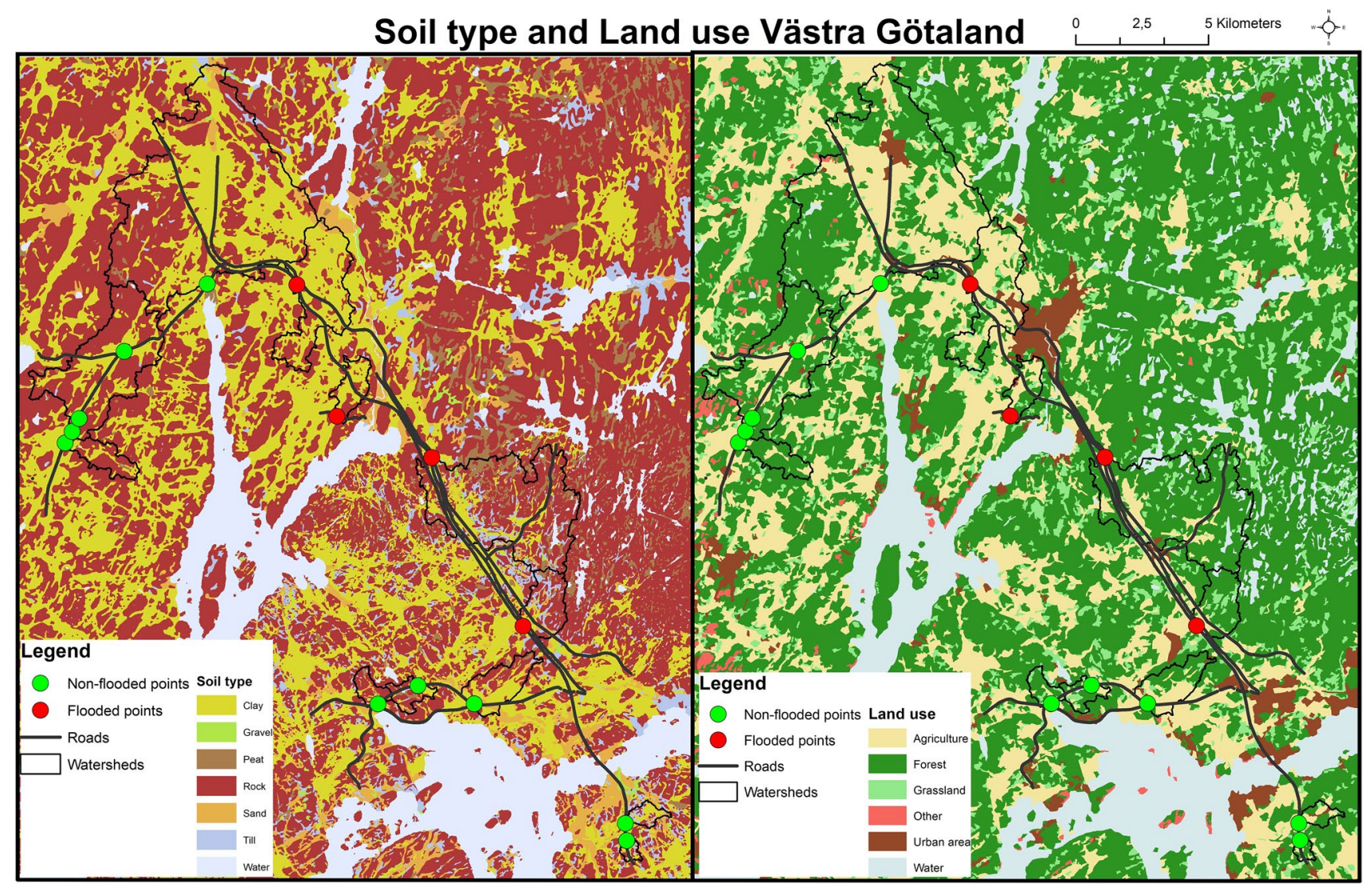

Fig. 2 Soil type and land use for Västra Götaland with flooded and non-flooded points, roads, and watersheds

in relative units between 0 and $100 \%$, comparing the wettest and the driest conditions. The soil moisture content, $\mathrm{m}_{\mathrm{s}}$, is estimated using $\sigma^{0}$ as the backscatter to be inverted, with $\sigma_{\text {wet }}^{0}$, the backscatter measurements, when wet and $\sigma_{\text {dry }}^{0}$ when dry (Wagner et al. 2013):

$m_{s}=\frac{\sigma^{0}-\sigma_{d r y}^{0}}{\sigma_{w e t}^{0}-\sigma_{d r y}^{0}}$.

The values are in decibels $(\mathrm{dB})$ at $40^{\circ}$ incidence angle and vary in time and space. This degree of saturation can be transformed to volumetric soil moisture content $\Theta$ by adding the soil porosity $\varphi$ to determine values with units $\mathrm{m}^{3} \mathrm{~m}^{-3}$ :

$\Theta=m_{s} \cdot \phi$.

The dielectric constant of soils increases with soil moisture content, and thus, the backscatter can be measured. The algorithm used is the TU-Wien change detection model, retrieves relative changes in soil moisture, and indirectly takes land cover and surface roughness into account (Barrett and Petropoulos 2012; Wagner et al. 1999a, b).

A small-scale surface soil moisture product with 1-km spatial resolution has been developed. This product is disaggregated and re-sampled from the original $25-\mathrm{km}$ product as a tool for hydrological processes and measures the top $0-2 \mathrm{~cm}$ of the soil. The conversion process includes a parameter database and a pre-computed fine-mesh layer that contains information about backscatter and scaling characteristics. This information is derived from finer resolution SAR images provided from Envisat ASAR while operating in ScanSAR global monitoring mode (Brocca et al. 2017; EUMETSAT 2017; Wagner et al. 2008, 2013).

Temporal dynamics of the soil moisture are assumed to be similar across scales, which enables a linear model to be created for the relationship between regional and local-scale measurements, where soil moisture at $1-\mathrm{km}$ scale can be derived from the $25-\mathrm{km}$ product using the following (Wagner et al. 2013):

$m_{\mathrm{s}}^{1 \mathrm{~km}}(t, x, y)=c_{\mathrm{ASAR}}(x, y)+d_{\mathrm{ASAR}}(x, y) m_{\mathrm{s}}^{25 \mathrm{~km}}(t)$,

where $m_{\mathrm{s}}^{1 \mathrm{~km}}$ is the estimated soil moisture at $1 \mathrm{~km}$ by the coordinates $(x, y)$ and $m_{\mathrm{s}}^{25 \mathrm{~km}}$ is the $25-\mathrm{km}$ soil moisture at time $t$. The coefficients $c_{\mathrm{ASAR}}$ and $d_{\mathrm{ASAR}}$, which are the scaling parameters, are derived from backscatter time series from ASAR. Considering that the downscaling parameters provided by ASAR are static, i.e., the temporal information is still derived from the original $25 \mathrm{~km}$ product; the value 

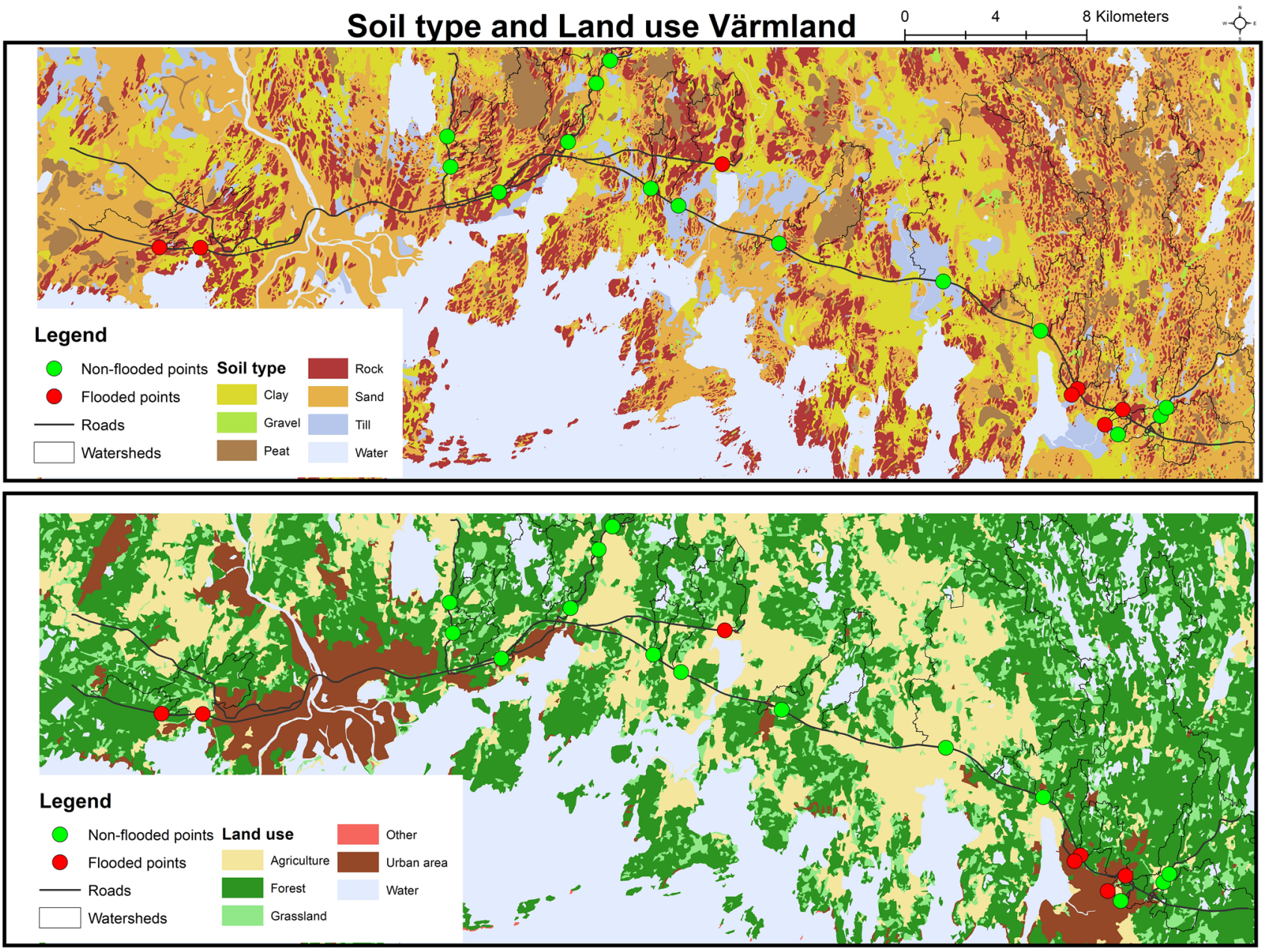

Fig. 3 Soil type and land use for Värmland with flooded and non-flooded points, roads, and watersheds

of the 1-km product is not yet clear. Nevertheless, it enables interpretation of soil moisture information at much finer resolution, which makes it valuable in applications where the spatial distribution is more important than the temporal dynamics (Wagner et al. 2013).

\section{SMOS}

The SMOS satellite is a passive microwave sensor, measured in L-band and thus at lower frequencies, so it is expected that vegetation and other perturbation effects have less impact (Lacava et al. 2012). L-band measurements limit the atmospheric contribution, and cloud cover and atmospheric water have insignificant effects. In vegetated areas, the L-band is more sensitive to soil moisture than in higher frequencies. The SMOS satellite measures volumetric soil moisture in units $\mathrm{m}^{3} / \mathrm{m}^{3}$ and has a temporal resolution of 2-3 days (Kerr et al. 2010; Seneviratne et al. 2010).

The algorithm used is a function of the brightness temperature from modeling of the surface (including knowledge about soil texture and land cover) and actual angular measurements. The brightness temperature is used to derive surface soil moisture (EO 2017; Kerr et al. 2010; Leroux et al. 2014). Large dielectric contrast can be identified between dry soil and water, and the soil emissivity depends on the moisture content (EO 2017). However, radio frequency interferences (RFI) can disturb and perturb the microwave emissions at some places and hence affect the retrieval of soil moisture data from SMOS (Albergel et al. 2012; Pierdicca et al. 2013).

\section{Results}

\section{Transport constructions and design}

In Västra Götaland, four out of five of the areas affected by flooding in 2014 lack a large road bridge (supplementary material C). At Hogsbotorpsmotet, culverts can be identified through Google Maps, although no outlet of the four visible 
culverts can be seen. However, it is expected to exist. The only flooded location with a bridge is Säleby, while five of the non-flooded areas that are studied have a large bridge registered in the database. Of eight flood-affected areas in Värmland, six lack a large road bridge. Smaller culverts are visible at three of these locations, but with undetermined standard and size. At Ikea, a stone culvert that is somewhat overgrown can be identified from Google Maps. At the nonflooded reference points, seven bridges are registered in the database. All road drainage constructions can be seen in Fig. 1. Ringvägen, and Rådmansgatan, which are connected by the same watercourse, were severely affected by the 2014 flooding. In this area, upstream dams and passing storm water flows also had consequences, together with a culvert owned by the municipality upstream from the road E18 that had restricted flow (Styffe 2017-05-19). Dimensioning of culverts upstream and downstream affects each other, and the occurrence and size of road constructions differ in this area. There are no large bridges or culverts at Lagmansgatan and only a small culvert at Kristinehamn E18 (Fig. 1 and supplementary material C). The road bridge at Rådmansgatan, with 4-m span width, was built in 2012 but was flooded in 2014, which indicates inadequate dimensioning in the design. Östra Ringvägen is located farthest downstream and that road bridge had a 5-m span width. However, it was washed away during the flood event, and has today been replaced by a new one with double the dimension (SVT 2014a, b).

\section{Radar measurement of precipitation}

According to SMHI ground station measurements, the precipitation amount in Västra Götaland in August 2014 was $218 \mathrm{~mm}$ at Uddevalla station and $179 \mathrm{~mm}$ at Heden station. In the last 10 years of monthly precipitation, these are the highest
In Kristinehamn, the locations Lagmansgatan, Östra

recorded values. The precipitation was the highest on the 19th of August, which is the day that the flooding occurred, with an average daily precipitation of $31.6 \mathrm{~mm}$ for the two stations. The highest precipitation values was recorded in Uddevalla, with $49 \mathrm{~mm}$ on the 19th of August (SMHI 2017a). The precipitation in Värmland in August 2014 was 290 mm for Väse station and $168 \mathrm{~mm}$ for Kristinehamn station. The daily precipitation was $59.7 \mathrm{~mm}$ on the 22nd of August and $61.9 \mathrm{~mm}$ on the 23rd of August, which is more than the average monthly rainfall in the area (SMHI 2017a).

The radar measurements showed low precipitation in Västra Götaland during the day of the 19th of August, but started to increase around 17:30 and continued to fall heavily until 21:15. From 20:00 in particular, the precipitation amounts increased greatly locally. At 20:15, Hällkista received $21.4 \mathrm{~mm}$ in $30 \mathrm{~min}$ (supplementary material D). The precipitation in Värmland started at 23:30 on the 20th of August and continued during the night to the 21st of August. The largest amounts hit Solberg and Silkesta with 46.9 and $42.6 \mathrm{~mm}$, respectively. Solberg had the highest precipitation rate, receiving $42.2 \mathrm{~mm}$ during $2 \mathrm{~h}$ (between 01:30 and 03:30) and $26.1 \mathrm{~mm}$ during $1 \mathrm{~h}$ (supplementary material D).

\section{ASCAT and SMOS soil moisture retrievals}

For the soil moisture values extracted from the satellites, a comparison to evaluate the data is presented in Fig. 4.

Since the ASCAT soil moisture product is a degree of saturation representing a relative value of the driest and wettest conditions in each cell and the SMOS data set is volumetric soil moisture in $\mathrm{m}^{3} / \mathrm{m}^{3}$, a conversion by linear transformation can be made (Fascetti et al. 2014):

$\frac{\mathrm{SMC}_{\mathrm{ASCAT}}-\min (\mathrm{SMC})}{\max (\mathrm{SMC})-\min (\mathrm{SMC})}=\frac{\mathrm{SMI}_{\mathrm{ASCAT}}}{100}$.

Fig. 4 Relationship between the ASCAT $25-\mathrm{km}$ resolution, ASCAT 1-km resolution, and SMOS satellite. The location shown is IKEA, Värmland

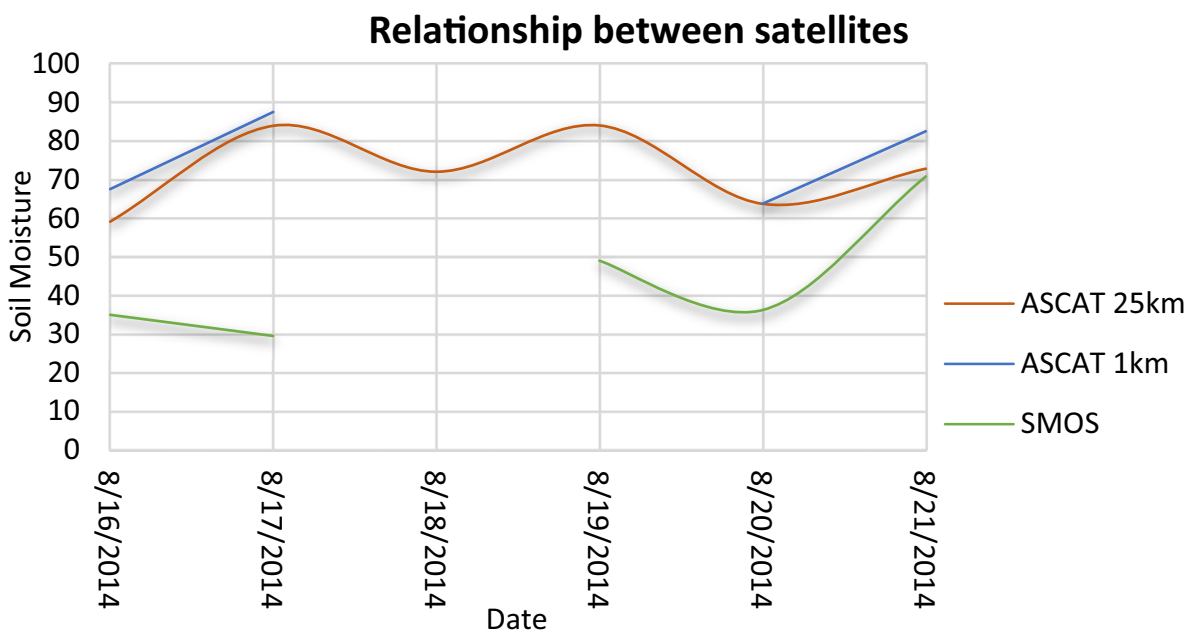


The ASCAT $1 \mathrm{~km}$ and the SMOS satellite missed data on some days, which explains the missing values in the diagram (Fig. 4). Overall, however, the three different satellites followed approximately the same pattern. The most prominent feature was a rise in values after the high rainfall on the night between the 20th and 21 st, which showed a high relationship between the satellites. The ASCAT $25 \mathrm{~km}$ and ASCAT $1 \mathrm{~km}$ are based on the same base data, since the $1-\mathrm{km}$ product is a disaggregated version of the $25-\mathrm{km}$ product. In a comparison between these two, the 1-km product had somewhat higher soil moisture values. Similarly, looking at all locations for 21 August in Värmland, the 1-km product had higher average soil moisture values $(90.5 \%)$ than the $25-\mathrm{km}$ product $(79.6 \%)$ (all results can be found in Online Resource 4).

In the average values of ASCAT $1 \mathrm{~km}$, Solberg had a relative soil moisture content of $100 \%$ in 11 out of 21 measurements (supplementary material E), which is questionable. It had $100 \%$ even on days with $0 \mathrm{~mm}$ of precipitation. The results for the 1-km product of Solberg were, therefore, excluded from average calculations. The location Karlabron also differed greatly from the rest, with extremely low values that were half the soil moisture values of the other sites, and it was, therefore, also excluded from average measurements considering the $1-\mathrm{km}$ product.

Another factor affecting the choice of satellite is the amount of No Data. The SMOS satellite had a lot of No
Data, with 52\% missing values for Värmland and 56\% for Västra Götaland. The ASCAT $1 \mathrm{~km}$ had $44 \%$ missing values during the dates of interest for Värmland and no values at all for Västra Götaland. This is due to the differences in temporal resolution and the disaggregating effects concerning the ASCAT 1-km product. Therefore, the ASCAT 25-km product was deemed most useful in this context.

The ASCAT 1-km product had no data for Västra Götaland during the period of interest. This was most likely because of the closeness to areas of water (which are excluded) and due to the disaggregating effect when downscaling from $25 \mathrm{~km}$ to $1 \mathrm{~km}$. Soil moisture information is only available if there is a sufficient temporal correlation between the local and regional backscatter information. The downscaling approach uses static parameters (from SAR data), and thus, the temporal variation of the $25-\mathrm{km}$ product drives the $1-\mathrm{km}$ product, and the soil moisture information is scaled down linearly for each grid point (Wagner et al. 2008). The $1-\mathrm{km}$ product is thus useful for spatial distribution at a higher spatial scale, but not sufficient when investigating temporal dynamics. The difference in spatial resolution can be seen in Fig. 5, where the catchment of Östra Ringvägen is investigated in more detail.

The days before the flooding, Västra Götaland received some medium amounts of precipitation before the heavier precipitation on the 19th of August. The relative soil
Soil Moisture $25 \mathrm{~km}$

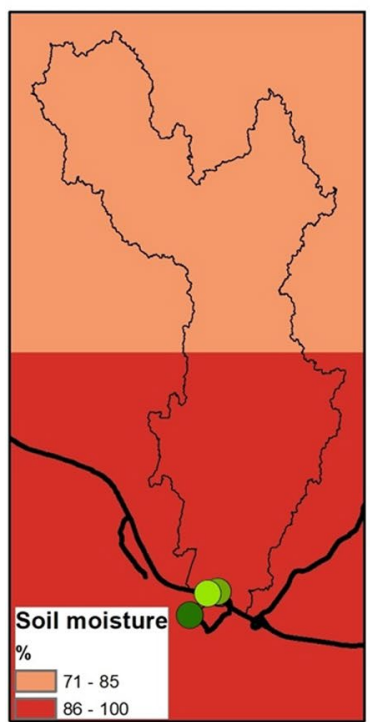

Rådmansgatan

Lagmansgatan

Östra Ringvägen
Soil Moisture $1 \mathrm{~km}$

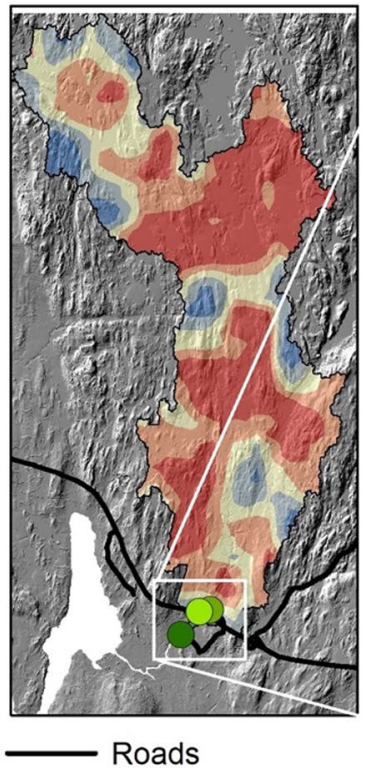

\section{Soil Moisture $1 \mathrm{~km}$}

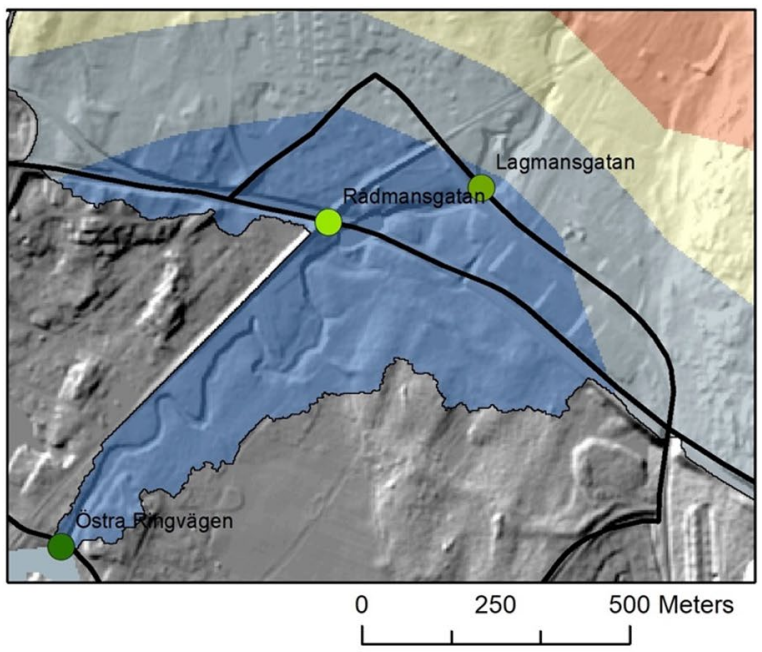

Soil Moisture $1 \mathrm{~km} \%$

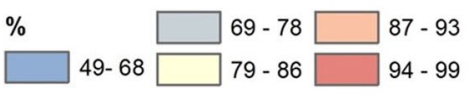

Östra Ringvägen catchment

Fig. 5 Soil moisture comparison between 25- and 1-km resolution for the catchment of Östra Ringvägen. The left images are the soil moisture with 25- and 1-km resolution for the whole catchment, while the right image is the lower part of the catchment 
moisture content increased during these days before the flooding, with peak values on the 19 th of $70.73 \%$ soil moisture with the ASCAT $25-\mathrm{km}$ satellite and $0.31 \mathrm{~m}^{3} / \mathrm{m}^{3}$ with SMOS (supplementary material E).

In general, the relative soil moisture content was much higher in Värmland than in Västra Götaland (supplementary material E). The flooding started on the 21st of August in Värmland, but the peak value of over $90 \%$ soil moisture (with ASCAT $25 \mathrm{~km}$ ) occurred on the 19th of August in the area of Väse (Väse Gamla E18, Väsemotet, Silkesta, Sorkan, and Östervik, see Fig. 1), and also at a location close to Kristinehamn (Östra Ringvägen). The soil moisture content was high in all areas on the 19th (average 85.2\%), despite the fact that the precipitation was relatively low. Interestingly, several of the areas were not flooded despite the high soil moisture content.

Most precipitation fell on the evening of the 20th and the following night, with $59.7 \mathrm{~mm}$ at Väse and $21.1 \mathrm{~mm}$ in Kristinehamn, which corresponded with the higher values of relative soil moisture content on the 21 st compared with the 20th. However, this was still lower than the 19th, although the high values might then have saturated the soil and enhanced the conditions for flooding on the 21st. Nevertheless, the high amounts of precipitation should have had a larger effect considering the much higher soil moisture values some days earlier with less precipitation.

The ASCAT 1-km product passes in both the ascending and descending phases, and, with its laterally directed antennae, measurements can be made several times a day. This is useful when examining how the relative soil moisture content changes during the day. The highest soil moisture content was recorded on the morning of the 21st of August, which correlates with the large amounts of precipitation that fell in the night between the 20th and 21st. The relative soil moisture content was, on average, $90.5 \%$ on the morning of the 21 st. The soil moisture was generally lower later in the day, most likely due to evapotranspiration but also the precipitation patterns during the day. At some locations in
Värmland, the soil moisture content increased in the evening due to increased precipitation amounts during the afternoon. However, the extremely large amounts of precipitation fell in the night, between the measurement at 18:57 on the 20th and the one at $08: 45$ on the 21 st, which corresponds with the soil moisture increase between those measurements.

The pattern of soil moisture content in Fig. 6 is similar to the pattern of the 15-min precipitation data (Berg et al. 2016). Higher precipitation resulted in most cases in a larger increase in soil moisture. The exceptions were Solberg and Silkesta in Värmland, with over $40 \mathrm{~mm}$ of precipitation but a smaller increase in soil moisture, and Båthamnen in Västra Götaland, with $26.92 \mathrm{~mm}$ of precipitation but a lower soil moisture content than areas with similar precipitation amounts.

\section{Connection between PCD, precipitation, and soil moisture}

From comparisons of the PCDs, precipitation, and soil moisture between the flooded and non-flooded areas, several results can be seen in table B in supplementary material, although the small number of areas investigated decreases the validity of the results.

- Larger slope generates more flooding. The average in Värmland was $2.59 \%$ slope for the flooded catchments and $1.33 \%$ for the non-flooded. In Västra Götaland, the flooded catchments had $1.25 \%$ slope and the non-flooded $0.98 \%$.

- Greater drainage density generates more flooding. The flooded areas in Värmland had $19.9 \mathrm{~m} / \mathrm{ha}$ in drainage density, which is $3.9 \mathrm{~m} / \mathrm{ha}$ more than the non-flooded, while the flooded areas in Västra Götaland had $15.5 \mathrm{~m} /$ ha, which is $2 \mathrm{~m} / \mathrm{ha}$ more drainage density than the nonflooded.

- Larger catchment size might lead to more flooding, but this finding is uncertain as too few catchments were
Fig. 6 Pattern of soil moisture content and precipitation for all investigated points In Västra Götaland and Värmland the 19-21st of August 2014

\section{Soil moisture and precipitation}

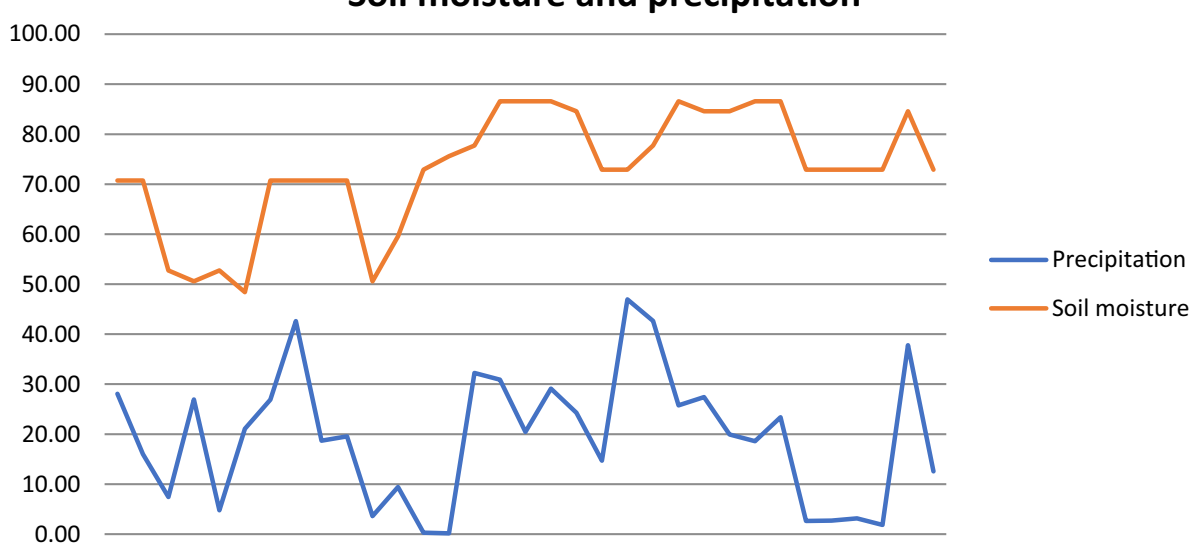


included. It applies for Värmland, but not Västra Götaland in this case.

- No conclusion can be drawn on the effect of soil type as all areas, flooded or non-flooded, in general, had glacial till or clay as the main soil type. The same applies for land use, where almost all catchments, both flooded and non-flooded, were characterized by forest.

- Precipitation is, on average, the same for flooded and non-flooded areas and smaller amounts of precipitation can still lead to flooding in some areas.

- More precipitation gives higher soil moisture values in most cases, but this does not necessarily generate more flooding.

The precipitation amounts in Västra Götaland, and thus the relative soil moisture content, were low in the days before the flooding. These small amounts should not have saturated the soil before the increase in precipitation on the 19th that caused the flooding. However, depending on the soil type and other preconditions in the catchment, several days with precipitation might have an impact when the intense rainfall occurred, thus creating the flood.

Kristinehamn in Värmland had high relative soil moisture content, although somewhat lower precipitation, but a large area of impermeable surfaces and a lack of sufficient road drainage structures. This was most likely the reason for the flooding in this area. In several cases, the flooding may have been due to sediment and water impeding culverts rather than the amount of precipitation received. With clogging of culverts by sediment, the consequences of increased precipitation are more severe.

\section{Discussion}

\section{Transport infrastructure damage and the role of drainage constructions (operation and maintenance)}

Roads can have an impact on the connectivity of a catchment through induced effects on flow paths, runoff, sediment transport, and erosion (Kalantari et al. 2017). It is, therefore, essential to adapt road maintenance and planning to increased flows of water, but also to an increase in the number of roads that affect the natural flood patterns and act as a barrier.

It is important for adaptation and maintenance to prioritize and direct actions towards road sections that are at risk of flooding. Cost-effective protection against sediment and water movements is necessary to ensure a safe and resilient transport system. Altering the current dimensioning of drainage facilities, identified as one contributing factor to the flooding in Kristinehamn, would be a good way to start. It is also important to consider the whole water course and catchment, including all contributing culverts upstream, as was seen in Östra Ringvägen catchment, where several road-stream interactions were affected. Differences in dimensioning and maintenance of the drainage facilities might have had an impact, and clogging of culverts and small dimensions affected the flow in the entire catchment. It is thus essential to adapt the dimensioning to future changes, including land use and climate changes.

Furthermore, consideration should be given to the characteristics of the roads, as road material, drainage efficiency, construction practices, location, and age of the road all affect the flood risk. Soil moisture, temperature, slope, basin geology, and precipitation characteristics further enhance the risk. Older roads located at stream intersections in low-lying areas with medium slopes were identified as gathering the most sediment and thus have a higher risk of flooding.

With increased development of roads, more impacts are observed on water levels and flood extent, duration, and velocity. At the same time, the implementation of drainage structures to allow water to pass under the roads is essential, and it is also critical to identify and maintain current structures. Another option might be to increase the elevation of the roads and to create dikes that can protect the road infrastructure. Overall, the infrastructure network needs to be constructed to prevent damage and to minimize the effects of sediment and water reaching the roads and increasing the potential flood risk.

\section{Remote-sensing soil moisture}

\section{Application difficulties and validating issues}

Applying satellite soil moisture data in, e.g., flood prediction involves some scientific and technical challenges. For many small and medium-scale applications, the coarse resolution of 25-50 km of many of the soil moisture-specific satellites, like ASCAT and SMOS, may not be sufficient. The first challenge thus involves changing perceptions about the usefulness of these products and taking them into account (Wagner et al. 2013). For example, studies by Brocca et al. (2012) show that soil moisture data from ASCAT can be efficiently employed in flood prediction for small and medium catchments, despite the coarse spatial resolution. The problem is to achieve higher spatial resolution while maintaining high temporal resolution. Disaggregation techniques that use external information to redistribute the soil moisture to a better spatial resolution are one promising approach (Kerr et al. 2010). For example, the ASCAT product has been disaggregated from 25 to a $1-\mathrm{km}$ product and studies have also disaggregated SMOS data (Merlin et al. 2006, 2008; Piles et al. 2014). The disaggregated 1-km soil moisture product from ASCAT is an 
important contribution to research, but the reliability of the results can be questioned. Values are only provided if there is a sufficient temporal correlation between regional and local backscatter. It is, therefore, usable for the spatial distribution, rather than temporal dynamics, as it uses static parameters. For this study, there were no available measurements for Västra Götaland, which restricted the use.

However, the long-term availability of data also has an important role, and from an application viewpoint, the high temporal resolution of these sensors is a great advantage, although a temporal resolution of 1.5 days means that the measurements can be made in the morning 1 day and in the evening another day. This affects the results, as, for example, evaporation during the day changes the values. However, with sufficient precipitation data available, this can be taken into account.

A general problem for remote-sensing data is the presence of vegetation and the seasonal variability, and in cases of dense canopies, the soil moisture data retrieval will be less accurate. Surface roughness has an impact, topography affects the angular measurements, snow and frozen soils induce some signals, and urban areas are not fully assessed considering their emissivity (Kerr et al. 2010). For the SMOS satellite, the influence of radio frequency interferences (RFI) can also have an impact on the retrieval outcome (Albergel et al. 2012; Kerr et al. 2010; Pierdicca et al. 2013). Another obstacle is that the presence of water within a measured pixel must be known to get acceptable accuracy, although water is variable and can change due to seasons, weather conditions, and human activity (Kerr et al. 2010). Open water, with no disturbance of wind that generates roughness, acts like a mirror where no backscatter signal is generated, which is good for the retrieval of soil moisture values (Gruber et al. 2013). If the water area is small compared with the area of the scatterometer footprint, it should not impact the retrieval of soil moisture data. However, in areas with large amounts of water, the soil moisture values will be affected (Bartalis et al. 2008).

Furthermore, problems with validating different studies are a consequence due to lack of practice and standards when handling satellite data and there are no agreed values for retrieval errors. This, in turn, causes problems for users when deciding which data are most suitable for a specific application. Currently, available remote-sensing measurements of soil moisture can, for example, only measure the top surface layer and some applications may require information about the entire unsaturated zone. If root zone soil moisture is required to a depth of $1-1.5 \mathrm{~m}$, satellite data are not sufficient. For observations of root zone soil moisture, the SWI (Soil Wetness Index) can instead be applied (Brocca et al. 2010). Using even lower frequencies could be an approach, but the spatial resolution would then be inappropriate and reduce the usability. Another indirect method could be the assimilation of ground surface measurements and simulations (Kerr et al. 2010; Wagner et al. 2013).

Validation of the results obtained by remote sensing is challenging. First, issues with sensing depth and scaling properties impede the interpretation. Second, soil moisture is a parameter that is highly variable in time and space, thus creating difficulties in comparing the irregular satellite measurements with reference data. Crow et al. (2012) discuss the issue of lack of reference data that represent the same physical quantity as the satellite measurements. Problems with ground measurements compared with satellites include differences in spatial resolution; for example, $50 \mathrm{~km}$ compared with point measurements, and the measuring depth, as an installed probe measures at a greater depth than $5 \mathrm{~cm}$. Modeled soil moisture data are also uncertain, as parameters like precipitation and soil properties affect the outcome. The correlation between satellite measurements, models, and in situ data can, therefore, be low. However, this does not mean that the satellite data are poor, but would rather depend on unrepresentative in situ data for large areas, or poor quality of the modeled data. The uncertainty factor in comparing and validating the results is thus an issue. Nevertheless, several validation studies and comparisons between ASCAT and SMOS have been performed and show good correlation (Albergel et al. 2012; Fascetti et al. 2014; Lacava et al. 2012; Leroux et al. 2014; Parrens et al. 2012; Pierdicca et al. 2013).

\section{Soil moisture data retrieval from satellite data}

Soil moisture has a high variability depending on scale and depth, particularly that in the top surface layer which is measured by remote-sensing techniques, as the top soil layer is affected by evaporation, vertical and lateral redistribution, topography on microscale, and varying soil properties (Wagner et al. 1999a, b). Including soil moisture can thus be problematic. Nevertheless, as soil moisture is fundamental in the infiltration process within a catchment, the assimilation of soil moisture data into runoff prediction models can highly improve the estimations.

In contrast to the conventional measurement methods, the use of remote sensing in estimating soil moisture content has the advantage that observations can be retrieved over a large area in a short time. The spatial distribution and frequency of the satellites enables daily to sub-daily measurement and, with the development of near real-time retrievals, the capabilities for high-quality soil moisture values are increasing.

The launch of specific soil moisture satellites, such as the SMOS satellite and the Soil Moisture Active Passive (SMAP) mission in 2015, with 36-km spatial resolution and 2-day temporal resolution, demonstrates the importance of 
including soil moisture data. Other satellites under development are the FengYun-3 and the WindSat Polarimetric Radiometer, which are being employed for soil moisture (Brocca et al. 2017). One promising option is the Sentinel-1 satellite, an SAR system with high-resolution C-band data. The fine spatial resolution of 5-20 m provides an attractive option for hydrological measurements at the catchment scale, and the temporal resolution is 6 days. Several studies have examined the use of Sentinel-1 data for retrieving soil moisture data, and the results indicate that there is high potential for global monitoring of surface soil moisture (Gruber et al. 2013; Hornacek et al. 2012; Petropoulos et al. 2015; Wagner et al. 2009). However, the launch of the Sentinel-1 mission was in April 2014, with full functionality in September 2014, and was thus not applicable to this study.

\section{Flood forecasting}

Soil moisture content is an important parameter in flood prediction models and will most likely be included in several future studies. SMHI is currently developing research into flood risks in cities and high-resolution radar precipitation data are part of this project (SMHI 2017b). The goal is to use the precipitation observations in real time to calculate the current soil moisture locally, and connect this to a detailed, high-resolution hydrological model. In this way, information on how water from a downpour flows when it reaches the surface in cities can be assessed, allowing prediction of fast increases in the flow after heavy precipitation events. Developing the use of high-resolution precipitation data and inclusion of several other parameters that have been identified as contributing factors to flooding is interesting considering the predicted increase in heavy precipitation and paved urban areas in the future.

\section{Conclusions}

This study tested different satellites to obtain soil moisture data. The results of analyzing PCDs, precipitation, and soil moisture show that larger slopes and drainage density, in general, mean higher risk of flooding. Larger catchments might have an enhanced risk of flooding, but the result is uncertain as more locations should be investigated for a more validated result. No conclusion can be drawn from the soil type or land use, as it varies between the flooded areas. The precipitation is the same; however, it can be concluded that more precipitation in most cases gives higher soil moisture values. The lack, or the dimensioning, of road drainage structures seems to have a large impact on the flood risk as more sediment and water can be accumulated at the roadstream intersection.

Some factors that affected the results:
Neither the ASCAT $1 \mathrm{~km}$ relative soil moisture data nor the radar precipitation data were calculated for each catchment in Värmland and Västra Götaland. For enhanced results, this should be performed. The limited information about the location of culverts smaller than $2 \mathrm{~m}$ in Sweden is a limitation to investigations like this. Good knowledge about how water and sediment move within a catchment in relation to the road infrastructure is essential for flood prediction.

However, several possibilities with the methods are identified. The use of satellite data creates abilities to measure soil moisture at a global scale and with less time needed. There is no need for time-consuming ground measurements and it decreases the costs of measuring. The near real-time possibilities of satellite data open the way for investigations of, e.g., soil moisture only a few hours after the measurements, which is an important factor when working with forecasting and prevention of flooding. The spatial and temporal consistency of satellite sensors creates huge potential for retrieving reliable soil moisture values. Further development of satellites with a better resolution and enhanced abilities to measure soil moisture characteristics will increase the quality of input data. Analysis of patterns of dynamic soil moisture will be enhanced with better spatial and temporal resolution and thus lead to more accurate results.

Acknowledgements This study arose from two research projects: (1) a project funded from The Swedish Research Council (Svenska Forskningsrådet) Formas (Grant 2014-754) and Bolin Center Research Area 7. The authors thank Eva Liljegren from Swedish Transportation Authority for her support and the anonymous reviewers for providing constructive comments about our paper. The authors would like to acknowledge networking support by the COST Action ES1306: Connecting European Connectivity Research.

Open Access This article is distributed under the terms of the Creative Commons Attribution 4.0 International License (http://creativeco mmons.org/licenses/by/4.0/), which permits unrestricted use, distribution, and reproduction in any medium, provided you give appropriate credit to the original author(s) and the source, provide a link to the Creative Commons license, and indicate if changes were made.

\section{References}

Ahlmer A (2017) Integrating remotely sensed hydrologic parameters into an index of sediment connectivity. Dissertation, KTH, Stockholm

Albergel C, de Rosnay P, Gruhier C, Muñoz-Sabater J, Hasenauer S, Isaksen L, Wagner W et al (2012) Evaluation of remotely sensed and modelled soil moisture products using global ground-based in situ observations. Remote Sens Environ 118:215-226. https:// doi.org/10.1016/j.rse.2011.11.017

Baghdadi N, Aubert M, Zribi M (2012) Use of TerraSAR-X Data to Retrieve Soil Moisture Over Bare Soil Agricultural Fields. IEEE Geosci Remote Sens Lett 9(3):512-516 
Barrett BW, Petropoulos GP (2012) Satellite remote sensing of surface soil moisture. In: Petropoulos GP (ed) Remote sensing of energy fluxes and soil moisture content. CRC Press, Boca Raton, pp 85-120

Bartalis Z, Wagner W, Naeimi V, Hasenauer S, Scipal K, Bonekamp $\mathrm{H}$ et al (2007) Initial soil moisture retrievals from the METOP-A Advanced Scatterometer (ASCAT). Geophys Res Lett 34:20. https ://doi.org/10.1029/2007GL031088

Bartalis Z, Naeimi V, Hasenauer S, Wagner W (2008) ASCAT soil moisture product handbook. Retrieved from ASCAT Soil Moisture Report Series, No. 15, Institute of Photogrammetry and Remote Sensing, Vienna University of Technology, Austria.: https://publik.tuwien.ac.at/files/PubDat_219464.pdf

Bates BC, Kundzewicz ZW, Wu S, Palutikof JP (2008) Climate Chang and Water. Technical Paper of the Intergovernmental Panel on Climate Change. http://www.ipcc.ch/pdf/technicalpapers/climate-change-water-en.pdf

Berg P, Norin L, Olsson J (2016) Creation of a high resolution precipitation data set by merging gridded gauge data and radar observations for Sweden. J Hydrol 541:6-13. https://doi. org/10.1016/j.jhydrol.2015.11.031

Berthet L, Andréassian V, Perrin C, Javelle P (2009) How crucial is it to account for the antecedent moisture conditions in flood forecasting? Comparison of event-based and continuous approaches on 178 catchments. Hydrol Earth Syst Sci 13(6):819-831. https ://doi.org/10.5194/hess-13-819-2009

Bohusläningen (2014-08-21) Regnkaoset i Munkedal. http://bohus laningen.se/nyheter/munkedal/1.3370086-regnkaos-i-munkedal. Accessed 1 Feb 2017

Bonn F, Dixon R (2005) Monitoring flood extent and forecasting excess runoff risk with RADARSAT-1 data. Nat Hazards 35(3):377-393. https://doi.org/10.1007/s11069-004-1798-1

Brencic M, Dawson A, Folkeson L, Francois D, Leitao T (2009) Chap. 12 Pollution Mitigation. In: Dawson A (ed) Water in road structures-Movement, drainage and effects. Springer, Dordrecht, pp 283-297

Brimicombe A (2009) GIS, Environmental Modeling and Engineering, 2nd edn. CRC Press, Boca Raton

Brocca L, Melone F, Moramarco T (2008) On the estimation of antecedent wetness conditions in rainfall-runoff modelling. Hydrol Process 22(5):629-642. https://doi.org/10.1002/hyp.6629

Brocca L, Melone F, Moramarco T, Wagner W, Naeimi V, Bartalis $\mathrm{Z}$, Hasenauer S (2010) Improving runoff prediction through the assimilation of the ASCAT soil moisture product. Hydrol Earth Syst Sci 14(10):1881-1893. https://doi.org/10.5194/ hess-14-1881-2010

Brocca L, Hasenauer S, Lacava T, Melone F, Moramarco T, Wagner W, Bittelli M (2011) Soil moisture estimation through ASCAT and AMSR-E sensors: An intercomparison and validation study across Europe. Remote Sens Environ 115(12):3390-3408. https ://doi.org/10.1016/j.rse.2011.08.003

Brocca L, Moramarco T, Melone F, Wagner W, Hasenauer S, Hahn S (2012) Assimilation of surface- and root-zone ASCAT soil moisture products into rainfall-runoff modeling. IEEE Trans Geosci Remote Sens 50(7):2542-2555. https://doi.org/10.1109/ TGRS.2011.2177468

Brocca L, Crow WT, Ciabatta L, Massari C, de Rosnay P, Enenkel M, Wagner W (2017) A review of the applications of ASCAT soil moisture products. IEEE J Select Topics Appl Earth Obs Remote Sens 10(5):2285-2306

Crow WT, Bindlish R, Jackson TJ (2005) The added value of spaceborne passive microwave soil moisture retrievals for forecasting rainfall-runoff partitioning. Geophys Res Lett, 32(18). https:// doi.org/10.1029/2005GL023543

Crow WT, Berg AA, Cosh MH, Loew A, Mohanty BP, Panciera R, Walker JP (2012) Upscaling sparse ground-based soil moisture observations for the validation of coarse-resolution satellite soil moisture products. Rev Geophys 50(2). https://doi. org/10.1029/2011RG000372

Entekhabi D, Njoku EG, O'Neill PE, Kellogg KH, Crow WT, Edelstein WN, Van Zyl J (2010) The soil moisture active passive (SMAP) mission. Proc IEEE 98(5):704-716. https://doi. org/10.1109/JPROC.2010.2043918

EO (2017) SMOS (Soil Moisture and Ocean Salinity) Mission. https ://directory.eoportal.org/web/eoportal/satellite-missions/s/ smos\#footback20\%29. Accessed 22 Apr 2017

EUMETSAT (2017) ASCAT soil moisture at $25 \mathrm{~km}$ Swath GridMetop. http://eoportal.eumetsat.int/discovery/Start/DirectSear ch/Extended.do?f(r0)=EO:EUM:DAT:METOP:SOMO25 Accessed 14 Feb 2017

European Commission (2007) Green Paper EU: Adapting to climate change in Europe-options for EU action. In: Green Paper from the Commission to the Council, the European Parliament, the European Economic and Social Committee and the Committee of the Regions COM(200)354 final. European Commission, Brussels

Fascetti F, Pierdicca N, Pulvirenti L, Crapolicchio R (2014). ASCAT and SMOS soil moisture retrievals: A comparison over Europe and Northern Africa. Paper presented at the Microwave Radiometry and Remote Sensing of the Environment (MicroRad), 2014 13th Specialist Meeting IEEE, pp 10-13

Gruber A, Wagner W, Hegyiová A, Greifeneder F, Schlaffer S (2013) Potential of Sentinel-1 for high resolution soil moisture monitoring. Paper presented at the Geoscience and Remote Sensing Symposium (IGARSS), 2013 IEEE International, pp 4030-4033

Hassaballa AA, Althuwaynee OF, Pradhan B (2014) Extraction of soil moisture from RADARSAT-1 and its role in the formation of the 6 December 2008 landslide at Bukit Antarabangsa, Kuala Lumpur. Arab J Geosci 7(7):2831-2840. https://doi. org/10.1007/s12517-013-0990-6

Holgersson B, Hedlund T, Ahlroth S, Frost C, Rosenqvist P, Thörn P (2007) Sverige inför klimatförändringarna - hot och möjligheter (SOU 2007:60). http://www.regeringen.se/rattsdokument/state ns-offentliga-utredningar/2007/10/sou-200760-/. Accessed 17 Feb 2017

Hornacek M, Wagner W, Sabel D, Truong HL, Snoeij P, Hahmann T, Doubkova M (2012) Potential for high resolution systematic global surface soil moisture Retrieval via change detection using Sentinel-1. IEEE J Select Topics Appl Earth Obs Remote Sens 5(4):1303-1311. https://doi.org/10.1109/JSTARS.2012.21901 36

Kalantari Z, Folkesson L (2013) Road drainage in Sweden: current practice and suggestions for adaptation to climate change. J Infrastruct Syst 19(2):147-156

Kalantari Z, Nickman A, Lyon SW, Olofsson B, Folkeson L (2014) A method for mapping flood hazard along roads. J Environ Manage 133:69-77. https://doi.org/10.1016/j.jenvman.2013.11.032

Kalantari Z, Lyon SW, Jansson P-E, Stolte J, French HK, Folkeson L, Sassner M (2015) Modeller subjectivity and calibration impacts on hydrological model applications: an event-based comparison for a road-adjacent catchment in south-east Norway. Sci Total Environ 502:315-329. https://doi.org/10.1016/j.scito tenv.2014.09.030

Kalantari Z, Cavalli M, Cantone C, Crema S, Destouni G (2017) Flood probability quantification for road infrastructure: datadriven spatial-statistical approach and case study applications. Sci Total Environ 581-582:386-398. https://doi.org/10.1016/j. scitotenv.2016.12.147

Karlsson CSJ, Kalantari Z, Mörtberg U, Olofsson B, Lyon SW (2017) Natural hazard susceptibility assessment for road planning using spatial multi-criteria analysis. Environ Manag. https://doi. org/10.1007/s00267-017-0912-6 
Kerr YH (2007) Soil moisture from space: where are we? Hydrogeol J 15(1):117-120. https://doi.org/10.1007/s10040-006-0095-3

Kerr YH, Waldteufel P, Wigneron JP, Delwart S, Cabot F, Boutin J, Mecklenburg S (2010) The SMOS Mission: New tool for monitoring key elements of the global water cycle. Proc IEEE 98(5):666687. https://doi.org/10.1109/JPROC.2010.2043032

Kornelsen KC, Coulibaly P (2013) Advances in soil moisture retrieval from synthetic aperture radar and hydrological applications. J Hydrol 476:460-489. https://doi.org/10.1016/j.jhydr ol.2012.10.044

Kron W, Berz G (2007) Flood disasters and climate change: Trends and options - A (re-)insurer's view. In: Lozán JL et al (ed) Global Change: Enough water for all? Hamburg, pp 268-273

Lacava T, Brocca L, Faruolo M, Matgen P, Moramarco T, Pergola N, Tramutoli V (2012) A multi-sensor (SMOS, AMSR-E and ASCAT) satellite-based soil moisture products inter-comparison. Paper presented at the Geoscience and Remote Sensing Symposium (IGARSS), 2012 IEEE International, pp 1135-1138

Lakshmi V (2013) Remote Sensing of Soil Moisture. ISRN Soil Science, 2013:33. https://doi.org/10.1155/2013/424178

Lenderink G, van Meijgaard E (2008) Increase in hourly precipitation extremes beyond expectations from temperature changes. Nat Geosci 1(8):511-514. https://doi.org/10.1038/ngeo262

Leroux DJ, Kerr YH, Bitar AA, Bindlish R, Jackson TJ, Berthelot B, Portet G (2014) Comparison between SMOS, VUA, ASCAT, and ECMWF soil moisture products over four watersheds in U.S. IEEE Trans Geosci Remote Sens 52(3):1562-1571. https://doi. org/10.1109/TGRS.2013.2252468

Merlin O, Chehbouni A, Kerr YH, Goodrich DC (2006) A downscaling method for distributing surface soil moisture within a microwave pixel: Application to the Monsoon '90 data. Remote Sens Environ 101(3):379-389. https://doi.org/10.1016/j.rse.2006.01.004

Merlin O, Walker JP, Chehbouni A, Kerr Y (2008) Towards deterministic downscaling of SMOS soil moisture using MODIS derived soil evaporative efficiency. Remote Sens Environ 112(10):3935-3946. https://doi.org/10.1016/j.rse.2008.06.012

Michielsen A, Kalantari Z, Steve LW, Liljegren E (2016) Predicting and communicating flood risk of transport infrastructure based on watershed characteristics. Environ Manage 182:505-518

Moran MS, Peters-Lidard CD, Watts JM, McElroy S (2004) Estimating soil moisture at the watershed scale with satellite-based radar and land surface models. Can J Remote Sens 30(5):805-826. https:// doi.org/10.5589/m04-043

Nigel A, Chunzhen L, Compagnucci R, da Cunha L, Hanaki K, Howe C, Döll P (2001) Chap. 4. Hydrology and Water Resources. In IPCC: http://www.ipcc.ch/ipccreports/tar/wg2/index .php?idp=166. Accessed 14 Feb 2017

Njoku EG, Jackson TJ, Lakshmi V, Chan TK, Nghiem SV (2003) Soil moisture retrieval from AMSR-E. IEEE Trans Geosci Remote Sens 41(2):215-229. https://doi.org/10.1109/TGRS.2002.808243

Nordlander H, Löfling P, Andersson O (2007) Bilaga B1. Vägverkets rapport till Klimat- och sårbarhetsutredningen-gruppen transporter. In: Klimat- och sårbarhetsutredningen SOU 2007:60. http://www.regeringen.se/49bbad/contentassets/94b5ab7c66 $604 \mathrm{~cd} 0 \mathrm{~b} 8842 \mathrm{fd} 6510 \mathrm{~b} 42 \mathrm{c} 9 /$ sverige-infor-klimatforandringarna ---hot-och-mojligheter-bilagedel-b-forteckning-bilaga-b-28-31sou-200760. Accessed 18 Apr 2017

Nya Kristinehamnsposten (2014-08-21) Vattenkaos efter nattens skyfall. http://nwt.se/kristinehamn/2014/08/21/vattenkaos-efter-natte ns-skyfall. Accessed 1 Feb 2017

Olsson J, Foster K (2013) Extrem korttidsnederbörd i klimatprojektioner för Sverige. http://www.smhi.se/polopoly_fs/1.29658!/ Klimatologi_6.pdf. Accessed 3 Mar 2017

Parrens M, Zakharova E, Lafont S, Calvet JC, Kerr Y, Wagner W, Wigneron JP (2012) Comparing soil moisture retrievals from
SMOS and ASCAT over France. Hydrol Earth Syst Sci 16(2):423440. https://doi.org/10.5194/hess-16-423-2012

Petropoulos GP, Griffiths H, Dorigo W, Xaver A, Gruber A (2013) Surface Soil Moisture Estimation. In: Petropoulos GP (ed) Remote Sensing of Energy Fluxes and Soil Moisture Content. CRC Press, Boca Raton, pp 29-48

Petropoulos GP, Ireland G, Barrett B (2015) Surface soil moisture retrievals from remote sensing: Current status, products and future trends. Phys Chem Earth 83-84:36-56. https://doi.org/10.1016/j. pce.2015.02.009

Pierdicca N, Pulvirenti L, Fascetti F, Crapolicchio R, Talone M (2013) Analysis of two years of ASCAT-and SMOS-derived soil moisture estimates over Europe and North Africa. Eur J Remote Sens 46(1):759-773. https://doi.org/10.5721/EuJRS20134645

Piles M, Sánchez N, Vall-llossera M, Camps A, Martínez-Fernández J, Martínez J, González-Gambau V (2014) A downscaling approach for SMOS land observations: Evaluation of high-resolution soil moisture maps over the Iberian Peninsula. IEEE J Select Topics Appl Earth Obs Remote Sens 7(9):3845-3857. https://doi. org/10.1109/JSTARS.2014.2325398

Pulvirenti L, Chini M, Pierdicca N, Guerriero L, Ferrazzoli P (2011) Flood monitoring using multi-temporal COSMO-SkyMed data: Image segmentation and signature interpretation. Remote Sens Environ 115(4):990-1002. https://doi.org/10.1016/j. rse.2010.12.002

Refice A, Capolongo D, Pasquariello G, D'Addabbo A, Bovenga F, Nutricato R, Pietranera L (2014) SAR and InSAR for flood monitoring: Examples with COSMO-SkyMed data. IEEE J Select Topics Appl Earth Obs Remote Sens 7(7):2711-2722. https://doi. org/10.1109/JSTARS.2014.2305165

Saran S, Sterk G, Nair R, Chatterjee RS (2014) Estimation of near surface soil moisture in a sloping terrain of a Himalayan watershed using ENVISAT ASAR multi-incidence angle alternate polarisation data. Hydrol Process 28(3):895-904. https://doi.org/10.1002/ hyp. 9632

Seneviratne SI, Corti T, Davin EL, Hirschi M, Jaeger EB, Lehner I, Teuling AJ (2010) Investigating soil moisture-climate interactions in a changing climate: a review. Earth Sci Rev 99(3-4):125-161. https://doi.org/10.1016/j.earscirev.2010.02.004

SMAP (2017) Soil Moisture-Dirt to Dinner. https://smap.jpl.nasa.gov/ classroom-activities/. Accessed 17 Apr 2017

SMHI (2017a) Öppna Data - Meterologiska observationer. http://opend ata-download-metobs.smhi.se/explore/. Accessed 11 Apr 2017

SMHI (2017b) Prognoser för översvämningsrisk i städer utvecklas. https://www.smhi.se/forskning/forskningsnyheter/prognoser-foroversvamningsrisk-i-stader-utvecklas-1.115064. Accessed 3 June 2017

Styffe S (2017-05-19) Personal communication, Trafikverket

Suarez P, Anderson W, Mahal V, Lakshmanan TR (2005) Impacts of flooding and climate change on urban transportation: a systemwide performance assessment of the Boston Metro Area. Transp Res Part D Transp Environ 10(3):231-244. https://doi. org/10.1016/j.trd.2005.04.007

Sveriges Radio (2014-08-21) Regn och översvämningar drabbar Värmland. http://sverigesradio.se/sida/artikel.aspx?progr amid=83\&artikel=5943235. Accessed 2 Feb 2017

SVT (2014a-08-21) Regnkaoset sprider sig. https://www.svt.se/nyhet er/lokalt/vast/regnkaoset-sprider-sig. Accessed 2 Feb 2017

SVT (2014b-10-14) Trumman som ska öppna vägen. http://www. svt.se/nyheter/lokalt/varmland/trumman-som-ska-oppna-vagen. Accessed 15 Mar 2017

Tague C, Band L (2001) Simulating the impact of road construction and forest harvesting on hydrologic response. Earth Surf Process Landf 26(2):135-151. https://doi.org/10.1002/10969837(200102)26:2<135::AID-ESP167>3.0.CO;2-J 
Trafikverket (2015) BaTMan - Bridge and Tunnel Management. https ://batman.vv.se/batman/logon/logon.aspx?url=https://batman.vv. se/batman/. Accessed 24 May 2017

Vägverket (2002) Ökade vattenflöden - Behov av åtgärder inom väghållningen. http://www.trafikverket.se/Foretag/Bygga-ochunderhalla/Vag/Tekniska-dokument/Bro-och-tunnel/Bro-ochtunnel---dokument/Okade-vattenfloden---Behov-av-atgarderinom-vaghallningen/. Accessed 20 Mar 2017

Vägverket (2008) VVMB 310 Hydraulisk dimensionering. https:// trafikverket.ineko.se/Files/sv-SE/11208/RelatedFiles/2008_61_ vvmb_310_hydraulisk_dimensionering.pdf. Accessed 13 Mar 2017

Wagner W, Lemoine G, Borgeaud M, Rott H (1999a) A study of vegetation cover effects on ERS scatterometer data. IEEE Trans Geosci Remote Sens 37(2):938-948

Wagner W, Lemoine G, Rott H (1999b) A method for estimating soil moisture from ERS scatterometer and soil data. Remote Sens Environ 70(2):191-207. https://doi.org/10.1016/S0034 -4257(99)00036-X

Wagner W, Pathe C, Doubkova M, Sabel D, Bartsch A, Hasenauer S, Löw A (2008) Temporal stability of soil moisture and radar backscatter observed by the Advanced Synthetic Aperture Radar (ASAR). Sensors 8(2):1174-1197
Wagner W, Sabel D, Doubkova M, Bartsch A, Pathe C (2009) The potential of Sentinel-1 for monitoring soil moisture with a high spatial resolution at global scale. Paper presented at the Symposium of Earth Observation and Water Cycle Science

Wagner W, Hahn S, Figa J, Albergel C, de Rosnay P, Brocca L, Dorigo W (2013) Operations, challenges, and prospects of satellite-based surface soil moisture data services. In: Petropoulos GP (ed) Remote Sensing of Energy Fluxes and Soil Moisture Content. CRC Press, Boca Raton, pp 463-488

Wang Y, Colby JD, Mulcahy KA (2002) An efficient method for mapping flood extent in a coastal floodplain using Landsat TM and DEM data. Int J Remote Sens 23(18):3681-3696. https://doi. org/10.1080/01431160110114484

Wemple B C, Swanson F J, Jones J A (2001) Forest roads and geomorphic process interactions, Cascade Range, Oregon. Earth Surf Process Landf 26(2): 191-204. https://doi.org/10.1002/10969837(200102)26:2<191::AID-ESP175>3.0.CO;2-U

Zhang F, Zhu X, Liu D (2014) Blending MODIS and Landsat images for urban flood mapping. Int J Remote Sens 35(9):3237-3253. https://doi.org/10.1080/01431161.2014.903351 